\title{
Preliminary experiments into the use of Streptomyces spp. isolated from peat in the biological control of soil and seed-borne diseases in peat culture
}

\author{
RISTO TAHVONEN
}

Department of Plant Pathology, University of Helsinki SF-00710 Helsinki 71, Finland

\begin{abstract}
Streptomyces spp. isolates obtained from peat effectively inhibited the growth of Alternaria brassicicola Wiltshire, Fusarium culmorum (W. G. Smith) Sacc., F. sulphureum Schlechtendahl, Pythium debaryanum auct. non Hesse and Rhizoctonia solani Kühn on PDA medium, but Streptomyces spp. isolates from fine sand soil were not effective against $F$. culmorum compared to the strains isolated from peat. Treatment of cauliflower seeds with Streptomyces spp. isolated from peat effectively controlled damping-off caused by $A$. brassicicola and $R$. solani when the seedlings were grown on either disinfected or fresh peat. Spraying the seeding layer of the peat substrate with a suspension of Streptomyces reduced the mortality of barley sprouts and foot rot caused by $F$. culmorum, and damping-off on sugar beet caused by $P$. debaryanum.
\end{abstract}

\section{Introduction}

In a number of studies carried out in 1975-1979 on the inhibitory effect of light-coloured Sphagnum fuscum peat on plant pathogens (TAHVONEN 1982), it was found that some of the peat lots prevented or reduced the damage caused by a number of soil and seed-borne fungal pathogens. The phenomenon was shown to be due to the action of certain microbes in the peat, of which Trichoderma viride Pers. ex Fr. and Streptomyces spp. were the most effective against fungal pathogens grown on growth media. In an experiment into the control of damping-off in cabbage, the effect of treatment with Streptomyces was greater and of longer duration than that with $T$. viride.

Since, as far as is known, Streptomyces species isolated from lightcoloured Sphagnum peat have not been tested in the biological control of fungal pathogens, further studies were carried out into the possibilities of using Streptomyces isolates obtained from peat as a biological control agent. Those pathogens and test plants which could be rapidly and easily used in testing and developing the methods and which, however, were important and/or typical soil and seed-borne fungal pathogens were selected for use in the study. 


\section{Material and methods}

Streptomyces isolates obtained from peat lots supplied by peat producers and growers were cultivated on PDA medium containing prothiocarp and benomyl fungicides to inhibit the effect of interfering fungi (TAHVONEN 1982). The Streptomyces isolates were stored and grown on a medium $(\mathrm{pH}$ about 7) containing $4 \mathrm{~g}$ yeast extract, $10 \mathrm{~g}$ malt extract, $4 \mathrm{~g}$ glucose and $20 \mathrm{~g}$ agar / $1000 \mathrm{ml}$ water. In addition to transfers carried out in the normal way with a needle, large amounts of Streptomyces spp. were transferred by spraying spore suspensions onto the surface of the medium. This ensured that the surface of the petri dish would be covered with mycelia. The spore suspensions were prepared by scraping off all the mycelia growing in a petri dish $(\varnothing=9 \mathrm{~cm})$ and mixing it with $50 \mathrm{ml}$ of sterile water using an Ultra Turrax homogeniser.

The isolates obtained from peat were tested against Alternaria brassicicola Wiltshire, Fusarium culmorum (W. G. Smith) Sacc., F. sulphureum Schlechtendahl, Pythium debaryanum auct. non Hesse and Rhizoctonia solani Kühn growing on PDA medium (TAHVONEN 1982). Streptomyces spp. isolates obtained from fine sand soil, supplied by the Department of Microbiology, University of Helsinki, were tested against $F$. culmorum in order to compare their effectiveness with isolates obtained from peat.

The stock solution of Streptomyces needed for the seed and soil treatments was prepared by homogenising the mycelia scraped off the surface of the medium with either pure, autoclaved water or a nutrient solution $(4 \mathrm{~g}$ yeast extract, $10 \mathrm{~g}$ malt extract, and $4 \mathrm{~g}$ glucose $/ 1000 \mathrm{ml} \mathrm{H}_{2} \mathrm{O}$ ). Unless otherwise stated, the Streptomyces stock solution mentioned in the tables or figures was prepared by mixing Isolate No. 6 with water.

Streptomyces Isolate No. 6 contained $5.6 \times 10^{10}-1.3 \times 10^{11}$ spores/ petri dish and Isolate No. 13 contained $4.6 \times 10^{9}-6.0 \times 10^{10}$ spores/dish. No counts were made on the other isolates. In the experiments shown in Tables 2, 3, 4, 5, 6 and 9, 2 dishes $/ 100 \mathrm{ml}$ were used, and in Fig. 4 and Tables 7 and 81 dish/ $100 \mathrm{ml}$. In the experiments shown in Fig. 4 and Table 8, the Streptomyces spp. homogenised in their own growing solution had been grown in a flatbottomed flask containing the nutrient solution without agar. There were $1.5 \times 10^{9}$ spores $/ \mathrm{ml}$ in this stock suspension.

In the seed treatment, the seeds were soaked for about $5 \mathrm{~min}$. in the stock suspension of Streptomyces or in aqueous dilutions as shown in the tables, and then dried overnight between sheets of filter paper. In the soil treatment, the seeding layer was sprayed with the stock suspension or with aqueous dilutions as shown in the tables, at a level of about $100 \mathrm{ml} / \mathrm{m}^{2}$.

Infection of the seeds was ensured by infecting cauliflower seeds with $A$. brassicicola or $R$. solani and barley seeds with F. culmorum or Helminthosporium sativum Pammel, King \& Bakke. The seeds were immersed in a fungal suspension containing 2-week-old fungal mycelia grown on PDA medium in a petri dish $(\varnothing=9 \mathrm{~cm})$ at a level of $1 \mathrm{dish} / 100 \mathrm{ml}$. The seeds were dried between filter paper in the laboratory. In the experiment in which soil was infected with $P$. debaryanum and $R$. solani, the fungal mycelium from 
one PDA petri dish was mixed with 51 of peat one week before sowing the sugar beet or cauliflower seeds.

The seeds were grown in plastic boxes (volume about $1 \mathrm{l}$ ) at a sowing density of 36 cauliflower seeds or 40 barley and sugar beet seeds/box. 3 or 4 replications of each were used. New peat was used as the growing substrate in all the experiments apart from that presented in Table 6, where steamdisinfected peat was used. The barley seedlings were grown for 3 weeks, the cauliflower seedlings for 3.5 to 4 weeks and the sugar beet seedlings for 6 weeks. Sprouting of the barley seeds was inventoried and the fresh-weight of the plants and degree of infection was determined at the end of the experiment using the scale $0-2$, where $0=$ healthy, $1=$ slightly damaged foot of the stem, 2 = severe foot damage or dead. The number of cabbage and sugar beet seedlings which developed and the number of seedlings suffering from damping-off were determined. However, the results are expressed in the tables as the number of healthy plants/seeds sown so as to include the number of seedlings affected by belowground damping-off. Wherever necessary, the results have been subjected to analysis of variance and the $\mathrm{LSD}_{\mathrm{t}_{0.05}}$ between the means calculated.

\section{Results}

Most of the Streptomyces spp. isolates (35) obtained from the peat were effective or very effective in inhibiting the growth of the test fungi on PDA medium (Table 1). On the other hand, the Streptomyces spp. strains isolated

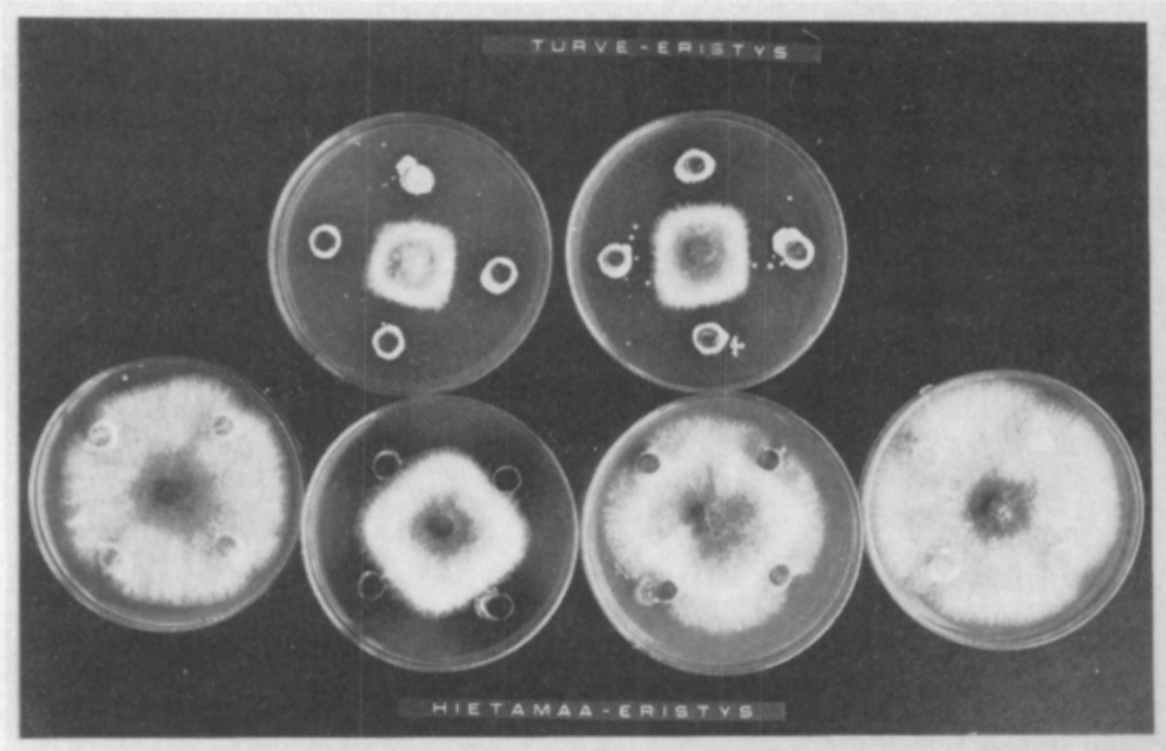

Fig. 1. Effect of Streptomyces spp. isolates obtained from peat and fine sand soil on the growth of Fusarium culmorum on PDA medium. Isolates in the top row made from peat and in the bottom row from fine sand soil. The $F$. culmorum transfer is in the centre of the dishes and the four Streptomyces transfers at the edge of the dishes. 
Table 1. Inhibitory effect of Streptomyces isolates obtained from peat and fine sand soil against different fungi on PDA medium.

\begin{tabular}{llccc}
$\begin{array}{l}\text { Origin of } \\
\text { Streptomyces } \\
\text { isolate }\end{array}$ & Test fungus & \multicolumn{3}{c}{$\begin{array}{l}\text { Strength of inhibitory effect, } \\
\text { number/number of isolates tested }\end{array}$} \\
\hline \multirow{2}{*}{ Peat } & & ineffective & medium & strong \\
& Alternaria brassicicola & $0 / 19$ & $5 / 19$ & $14 / 19$ \\
& Fusarium culmorum & $6 / 30$ & $10 / 30$ & $14 / 30$ \\
& F. sulphureum & $2 / 24$ & $3 / 24$ & $19 / 24$ \\
& Pythium debaryanum & $5 / 24$ & $3 / 24$ & $16 / 24$ \\
Fine sand soil & Rhizoctonia solani & $4 / 31$ & $4 / 31$ & $23 / 31$ \\
& F. culmorum & $16 / 20$ & $4 / 20$ & $0 / 20$ \\
\hline
\end{tabular}

Table 2. Effectiveness of different Streptomyces isolates in controlling damping-off caused by Alternaria brassicicola on cauliflower. Plants grown for 4 weeks.

\begin{tabular}{|c|c|c|c|c|}
\hline \multirow{2}{*}{$\frac{\text { Streptomyces }}{\text { isolate No. }}$} & \multicolumn{2}{|c|}{ Seed treatment } & \multicolumn{2}{|c|}{ Soil treatment } \\
\hline & emergence- $\%$ & healthy plants, \% & emergence- $\%$ & healthy plants, \% \\
\hline 1 & 75.9 & 63.9 & 46.2 & 23.1 \\
\hline 2 & 85.1 & 75.8 & 51.7 & 32.2 \\
\hline 3 & 58.3 & 54.4 & 32.4 & 15.6 \\
\hline 4 & 87.7 & 82.0 & 39.7 & 15.6 \\
\hline 5 & 72.2 & 61.0 & 52.8 & 20.3 \\
\hline 6 & 81.4 & 71.1 & 52.8 & 35.0 \\
\hline 7 & 36.1 & 19.4 & 37.8 & 15.6 \\
\hline 8 & 65.6 & 52.8 & 40.6 & 23.1 \\
\hline 9 & 61.1 & 48.9 & 30.6 & 19.4 \\
\hline 10 & 72.2 & 55.5 & 56.4 & 32.2 \\
\hline 11 & 55.6 & 45.3 & 35.0 & 22.2 \\
\hline 12 & 75.0 & 61.9 & 59.2 & 32.2 \\
\hline control & 14.7 & 5.6 & 14.7 & 5.6 \\
\hline healthy seeds & 89.8 & 89.8 & 89.8 & 89.8 \\
\hline
\end{tabular}

from mineral soil either did not inhibit at all or else only moderately inhibited the growth of Fusarium culmorum (W. G. Smith) Sacc. (Fig. 1 and Table 1).

In the seedling growing experiment, a number of Streptomyces spp. isolates, e.g. 1, 2, 4, 6, 10 and 12, effectively controlled damping-off caused by Alternaria brassicicola Wiltshire on cauliflower (Table 2). When the seed treatment was used, the control result was almost the same as for healthy seeds. However, the results obtained with the soil treatment were always significantly inferior to those for the seed treatment. Treatment of barley. seed with Streptomyces spp. decreased the amount of damage caused by F. culmorum and Helminthosporium sativum Pamel, King \& Bakke and increased the growth in fresh weight. Isolate No 2 reduced the incidence of damage and increased the growth in fresh weight of non-infected seeds where pathogens were found to occur naturally (Table 3 ). When the Streptomyces spp. treatment was given by spraying the seeding layer, the result for 
Table 3. Effect of different concentrations of Streptomyces sp. isolates on the germination, disease index and fresh growth after 3 weeks of non-infected barley seed and barley seed infected with Fusarium culmorum, Helminthosporium sativum suspensions.

\begin{tabular}{lllll} 
seed treatment & $1 / 1$ & $1 / 2$ & $1 / 5$ & $1 / 10$ \\
\cline { 2 - 4 } & sprouting- $\% /$ infection degree index, $0-2 /$ fresh yield, $\mathrm{g} /$ dish
\end{tabular}

\begin{tabular}{|c|c|c|c|c|c|}
\hline \multirow[b]{2}{*}{ Isolate 1} & \multirow[b]{2}{*}{$72 / 0.62 / 28.3$} & \multicolumn{3}{|c|}{ Seeds infected with Fusarium culmorum } & \multirow{2}{*}{$\begin{array}{c}\bar{X} \\
70 / 0.66 / 27.3\end{array}$} \\
\hline & & $68 / 0.69 / 20.8$ & $66 / 0.73 / 28.5$ & $76 / 0.60 / 31.7$ & \\
\hline Isolate 2 & $62 / 0.45 / 23.8$ & $40 / 0.76 / 16.2$ & $50 / 0.48 / 24.1$ & $60 / 0.60 / 26.0$ & $54 / 0.57 / 22.5$ \\
\hline Isolate 3 & $58 / 0.98 / 14.9$ & $66 / 0.99 / 15.9$ & $56 / 0.78 / 16.2$ & $48 / 0.87 / 16.2$ & $58 / 0.91 / 15.8$ \\
\hline control & $52 / 1.07 / 12.4$ & $52 / 1.07 / 12.4$ & $52 / 1.07 / 12.4$ & $52.1 .07 / 12.4$ & $52 / 1.07 / 12.4$ \\
\hline \multirow[t]{2}{*}{$\overline{\mathrm{X}}$ (isolate 1-3) } & $64 / 0.68 / 22.3$ & $58 / 0.81 / 17.6$ & $57 / 0.66 / 22.9$ & $61 / 0.69 / 24.6$ & $61 / 0.71 / 21.9$ \\
\hline & \multicolumn{5}{|c|}{ Seeds infected with Helminthosporium sativum } \\
\hline Isolate 1 & $94 / 0.56 / 39.4$ & $92 / 0.63 / 39.6$ & $92 / 0.74 / 39.9$ & $92 / 0.82 / 34.8$ & $92 / 0.69 / 38.4$ \\
\hline Isolate 2 & $82 / 0.30 / 22.8$ & $84 / 0.61 / 23.9$ & $94 / 0.19 / 33.2$ & $88 / 0.49 / 39.2$ & $88 / 0.40 / 29.8$ \\
\hline Isolate 3 & $92 / 0.67 / 39.2$ & $90 / 0.79 / 30.7$ & $90 / 0.68 / 32.6$ & $88 / 0.90 / 19.3$ & $90 / 0.76 / 30.5$ \\
\hline control & $90 / 0.72 / 30.0$ & $90 / 0.72 / 30.0$ & $90 / 0.72 / 30.0$ & $90 / 0.72 / 30.0$ & $90 / 0.72 / 30.0$ \\
\hline \multirow[t]{2}{*}{$\overline{\mathrm{X}}$ (isolate 1-3) } & $89 / 0.51 / 33.8$ & $89 / 0.68 / 31.4$ & $92 / 0.54 / 35.2$ & $89 / 0.74 / 31.1$ & $90 / 0.62 / 32.9$ \\
\hline & \multicolumn{5}{|c|}{ Non-infected seeds } \\
\hline Isolate 1 & $94 / 0.35 / 37.0$ & $90 / 0.28 / 37.2$ & $90 / 0.38 / 42.3$ & $96 / 0.44 / 37.1$ & $90 / 0.36 / 38.4$ \\
\hline Isolate 2 & $94 / 0.12 / 27.6$ & $98 / 0.07 / 27.3$ & $92 / 0.09 / 42.6$ & $92 / 0.17 / 40.4$ & $94 / 0.11 / 34.5$ \\
\hline Isolate 3 & $94 / 0.33 / 41.1$ & $90 / 0.53 / 40.5$ & $90 / 0.40 / 33.3$ & $92 / 0.48 / 27.6$ & $92 / 0.44 / 35.6$ \\
\hline control & $92 / 0.28 / 23.0$ & $94 / 0.28 / 23.0$ & $94 / 0.28 / 23.0$ & $94 / 0.28 / 23.0$ & $94 / 0.28 / 23.0$ \\
\hline$\overline{\mathrm{X}}$ (isolate 1-3) & $94 / 0.27 / 35.2$ & $93 / 0.27 / 35.0$ & $91 / 0.27 / 37.2$ & $93 / 0.27 / 35.0$ & $93 / 0.30 / 36.2$ \\
\hline
\end{tabular}

Table 4. Effect of different Streptomyces sp. isolates on the germination, degree of infection and fresh growth after 3 weeks of barley seeds infected with Fusarium culmorum. Soil and seed treatments carried out with different Streptomyces dilutions.

\begin{tabular}{|c|c|c|c|c|c|c|}
\hline & & \multicolumn{5}{|c|}{ Dilution made from stock Streptomyces suspension } \\
\hline & & $1 / 1$ & $1 / 2$ & $1 / 5$ & $1 / 10$ & $\mathrm{X}$ \\
\hline & & \multicolumn{5}{|c|}{ sprouting- $\%$ / infection degree index, $0-2$ / fresh yield $\mathrm{g} /$ dish } \\
\hline \multicolumn{7}{|l|}{ Seed treatment } \\
\hline Isolate 1 & & $60 / 1.09 / 8.6$ & $60 / 0.96 / 8.3$ & $73 / 0.88 / 10.2$ & $78 / 0.96 / 14.5$ & 68/0.97/10.4 \\
\hline Isolate 2 & & $78 / 0.65 / 14.1$ & $76 / 0.70 / 12.7$ & $63 / 0.81 / 6.5$ & $75 / 0.83 / 11.2$ & $73 / 0.75 / 11.1$ \\
\hline \multirow{2}{*}{ Isolate 3} & & $71 / 0.92 / 8.5$ & $40 / 1.06 / 3.4$ & $73 / 0.81 / 11.6$ & $77 / 0.75 / 13.5$ & $65 / 0.89 / 9.3$ \\
\hline & $\overline{\mathrm{X}}$ & $70 / 0.89 / 10.4$ & $59 / 0.91 / 8.1$ & $70 / 0.83 / 9.4$ & $77 / 0.85 / 13.1$ & $69 / 0.87 / 10.3$ \\
\hline \multicolumn{7}{|l|}{ Soil treatment } \\
\hline Isolate 1 & & $83 / 0.66 / 12.8$ & $80 / 0.79 / 18.7$ & $81 / 0.69 / 11.2$ & $84 / 0.74 / 18.3$ & $82 / 0.72 / 15$ \\
\hline Jsolate 2 & & $83 / 0.66 / 12.3$ & $83 / 0.67 / 14.6$ & $83 / 0.64 / 16.6$ & $84 / 0.77 / 21.9$ & $83 / 0.69 / 16$. \\
\hline \multirow[t]{2}{*}{ Isolate 3} & & $77 / 0.69 / 15.2$ & $73 / 0.81 / 13.5$ & $82 / 0.87 / 12.4$ & $81 / 0.75 / 15.4$ & $78 / 0.78 / 14$ \\
\hline & $\overline{\mathrm{X}}$ & $81 / 0.67 / 13.4$ & $79 / 0.76 / 15.6$ & $82 / 0.73 / 13.4$ & $83 / 0.75 / 18.5$ & $81 / 0.73 / 15.3$ \\
\hline Control & & $46 / 1.16 / 3.7$ & & & & \\
\hline Non-infected seed & & $89 / 0.29 / 18.7$ & & & & \\
\hline
\end{tabular}




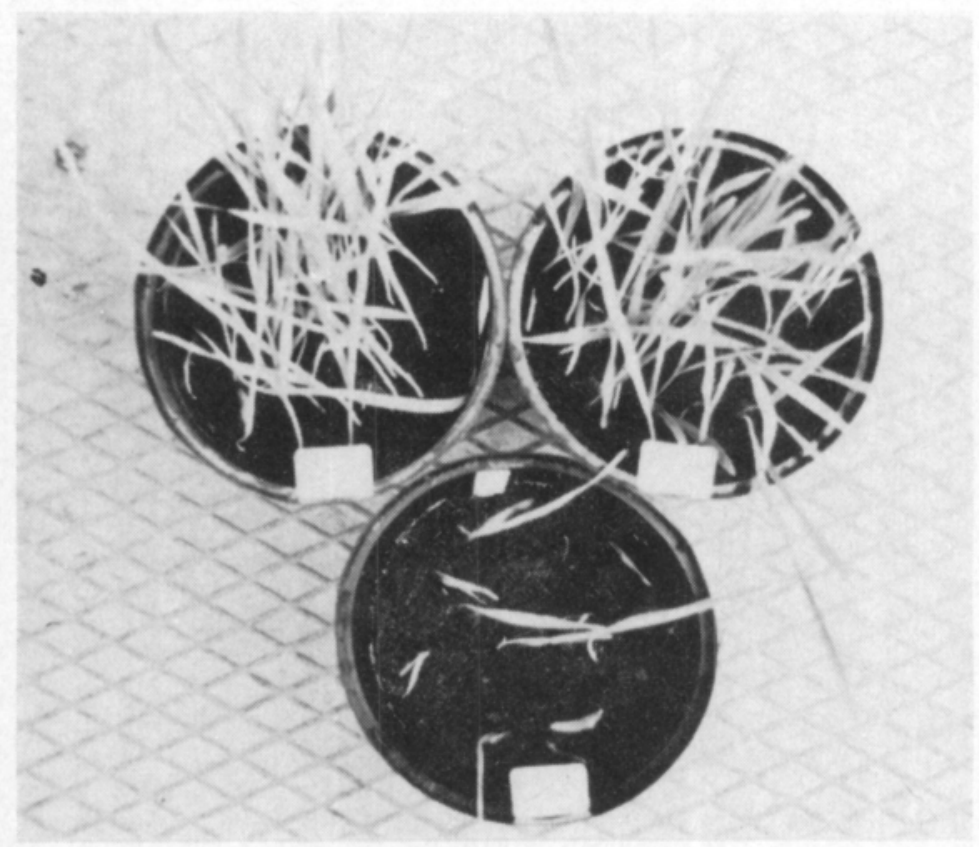

Fig. 2. Effect of spraying the seeding layer with Streptomyces sp. on the damage caused by Fusarium culmorum on barley. Bottom dish = untreated seeds infected with $F$. culmorum, upper right-hand dish = untreated, uninfected seeds; upper left-hand dish = seeds infected with $F$ culmorum and seeding layer sprayed with Streptomyces suspension.

protection against $F$. culmorum improved significantly in comparison to the results for the seed treatment. Sprouting was at the same level as the uninfected seeds when the soil treatment was carried out, and the fresh weight of the shoots was of the same order of magnitude as for the noninfected barley and four times greater than that of the controls (Table 4). Diluting the stock solution to $10 \%$ had no effect on the control results (Tables 3 and 4).

When the stock suspension of Streptomyces used for treating the cauliflower seeds against $A$. brassicicola and for the soil treatment against $F$. culmorum on barley, the nutrients used in the growth medium being added to the suspension, was tested, it was found that the stock solution could be diluted to at least $10^{-6}$ without any significant weakening of the control results (Tables 5 and 6). When dilutions were made with water, the control results deteriorated at dilutions below $10^{-2}$. Mixing different Streptomyces isolates in the same stock solution had no effect on the control result.

When the Streptomycetes sp. to be used as the stock suspension was grown in the nutrient solution and then homogenised in the original growing solution, and dilutions made with the suspension, it gave as good or better results in controlling seed-borne damping-off caused by $A$. brassicicola and Rhizoctonia solani Kühn on cauliflower, and in the control of F. culmorum on barley, than when the stock suspension was homogenised in a new nutrient medium (Fig 3 and Table 7). 


\section{HEALTHY SEEDLINGS}
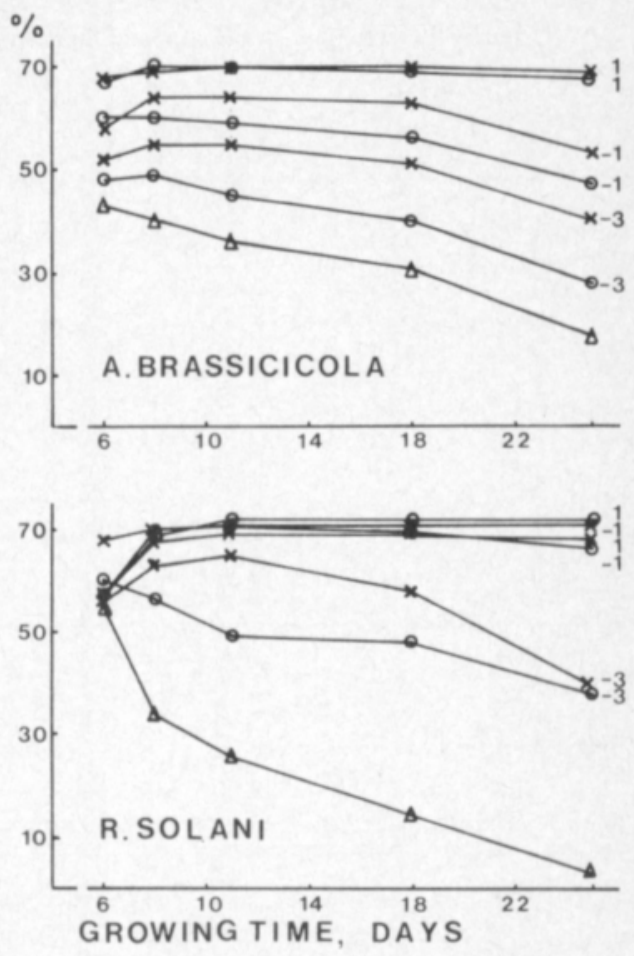

$\triangle=$ CONTROL, O=STREPTOMYCES SP. HOMOGENIZED INTO ITS OWN GROWTH SOLUTION, $\mathbf{X}=$ STREPTOMYCES SP. HOMOGENIZED INTO NEW GROWTH SOLUTION

1: STREPTOMYCES SP.STOCK SUSPENSION, $-1=10^{-1}$ AND $-3=10^{-3}$ DILUTION

Table 5. Effect of nutrient solution and dilutions on the effectiveness of Streptomyces sp. treatment of seeds in controlling damping-off caused by Alternaria brassicicola.

Streptomyces Dilution made from stock Streptomyces suspension

$\begin{array}{llllll}\text { isolate No } & 1 & 10^{-1} & 10^{-2} & 10^{-4} & 10^{-6}\end{array}$

Aqueous

\begin{tabular}{|c|c|c|c|c|c|c|c|}
\hline \multirow[t]{4}{*}{ Streptomyces suspension } & 6 & & $92.6 / 91.7$ & $84.3 / 82.4$ & $82.4 / 79.6$ & $57.4 / 40.7$ & $54.6 / 34.3$ \\
\hline & 13 & & $91.7 / 89.8$ & $89.8 / 85.2$ & $59.3 / 49.1$ & $48.1 / 37.0$ & $40.7 / 26.9$ \\
\hline & $6+13$ & & $92.6 / 90.7$ & $86.1 / 78.7$ & $46.3 / 35.2$ & $60.2 / 49.1$ & $39.8 / 21.3$ \\
\hline & & $\overline{\mathrm{X}}$ & $92.3 / 90.7$ & $86.7 / 82.1$ & $62.7 / 54.6$ & $55.2 / 42.3$ & $45.0 / 27.5$ \\
\hline \multicolumn{8}{|l|}{ Nutrient } \\
\hline \multirow[t]{5}{*}{ Streptomyces suspension } & 6 & & $91.7 / 87.0$ & $89.8 / 89.8$ & $75.9 / 65.7$ & $80.6 / 65.7$ & $76.9 / 69.4$ \\
\hline & 13 & & $90.7 / 90.7$ & 79.6/77.8 & $74.1 / 70.4$ & $62.0 / 50.0$ & $87.0 / 79.6$ \\
\hline & $6+13$ & & $90.7 / 88.0$ & $85.2 / 80.6$ & $64.8 / 61.1$ & $80.6 / 70.4$ & $82.4 / 77.8$ \\
\hline & & $\bar{x}$ & $91.0 / 88.6$ & $84.9 / 82.7$ & $71.6 / 65.7$ & $74.4 / 62.0$ & $82.1 / 75.6$ \\
\hline & control & & $44.4 / 29.6$ & & & & \\
\hline
\end{tabular}

emergence- $\% /$ healthy plants, $\%$ 
Table 6. Effect of nutrients added to the stock Streptomyces suspension and dilutions when carrying out soil treatment on the incidence of seed-borne foot rot disease caused by Fusarium culmorum in barley grown on steam-disinfected peat substrate.

\begin{tabular}{|c|c|c|c|c|c|c|c|}
\hline & \multicolumn{6}{|c|}{ Dilution made from stock suspension } & \multirow[b]{2}{*}{$\overline{\mathrm{X}}$} \\
\hline & Isolate & 1 & $10^{-1}$ & $10^{-2}$ & $10^{-4}$ & $10^{-6}$ & \\
\hline & & \multicolumn{5}{|c|}{$\%$ healthy plants 3 weeks after sowing } & \\
\hline \multirow[t]{4}{*}{ Aqueous stock suspension } & 6 & $\overline{72.2}$ & 63.9 & 67.6 & 53.7 & 51.9 & 61.9 \\
\hline & 13 & 79.6 & 65.7 & 68.5 & 52.8 & 60.2 & 65.4 \\
\hline & $6+13$ & 74.1 & 77.7 & 67.6 & 59.3 & 64.8 & 68.7 \\
\hline & $\overline{\mathrm{x}}$ & $\overline{75.3}$ & 69.1 & 67.9 & 55.3 & 58.9 & 65.3 \\
\hline \multirow[t]{4}{*}{ Nutrient stock suspension } & 6 & 82.4 & 74.1 & 74.1 & 75.0 & 57.4 & 72.6 \\
\hline & 13 & 73.1 & 79.6 & 78.7 & 71.3 & 75.0 & 75.5 \\
\hline & $6+13$ & 72.2 & 73.2 & 69.4 & 70.4 & 70.4 & 71.1 \\
\hline & $\overline{\mathrm{X}}$ & 75.9 & 75.6 & 74.1 & 72.2 & 67.6 & 73.1 \\
\hline Control & $\overline{\mathrm{X}}$ & 53.7 & & & & & \\
\hline Healthy seeds & $\overline{\mathrm{X}}$ & 78.7 & & & & & \\
\hline
\end{tabular}

Table 7. Effect of Streptomyces suspensions homogenised in the nutrient solution and in the original growing solution when carrying out soil treatment on the incidence of seed-borne foot rot caused by Fusarium culmorum on barley.

Stock Streptomyces solution

Dilution made from stock suspension

$1 \quad 10^{-1} \quad 10^{-3}$

control

Homogenised in fresh

nutrient solution

$\begin{array}{lcccc}\text { fresh yield, g/dish } & 18.7 & 18.8 & 16.6 & 11.9 \\ \text { degree of infection, } 0-2 & 0.53 & 0.67 & 0.53 & 0.67\end{array}$

Homogenised in original

growing solution

fresh yield, $\mathrm{g} /$ dish

degree of infection, $0-2$

24.4

21.9

14.1

11.9

0.15

0.32

0.62

$L S D_{t_{0.05}}:$ fresh yield $=5.2 \mathrm{~g}$, degree of infection $=0.28$

Table 8. Effect of the Streptomyces sp. treatment on the incidence of soil-borne damping-off caused by Rhizoctonia solani on cauliflower growing on peat substrate.

\begin{tabular}{|c|c|c|c|c|c|c|}
\hline \multirow{2}{*}{ Stock Streptomyces suspension } & \multirow{2}{*}{$\begin{array}{l}\text { Seed } \\
\text { treatment }\end{array}$} & \multicolumn{5}{|c|}{ Seed treatment + soil treatment, different dilutions } \\
\hline & & 1 & $10^{-1}$ & $10^{-2}$ & $10^{-3}$ & control \\
\hline \multicolumn{7}{|l|}{ Aqueous suspension } \\
\hline emergence-\% & 75.0 & 77.1 & 79.9 & 76.4 & 77.1 & 77.1 \\
\hline healthy plants, \% & 70.8 & 47.2 & 61.1 & 15.3 & 64.6 & 31.3 \\
\hline \multicolumn{7}{|l|}{ Nutrient suspension } \\
\hline emergence- $\%$ & 78.5 & 78.5 & 84.0 & 83.3 & 84.7 & 77.1 \\
\hline healthy plants, $\%$ & 63.9 & 51.4 & 42.4 & 66.0 & 56.9 & 31.3 \\
\hline
\end{tabular}

F values for healthy plants: aqueous suspension $=5.35^{* *}$, nutrient suspension $=0.70$. 


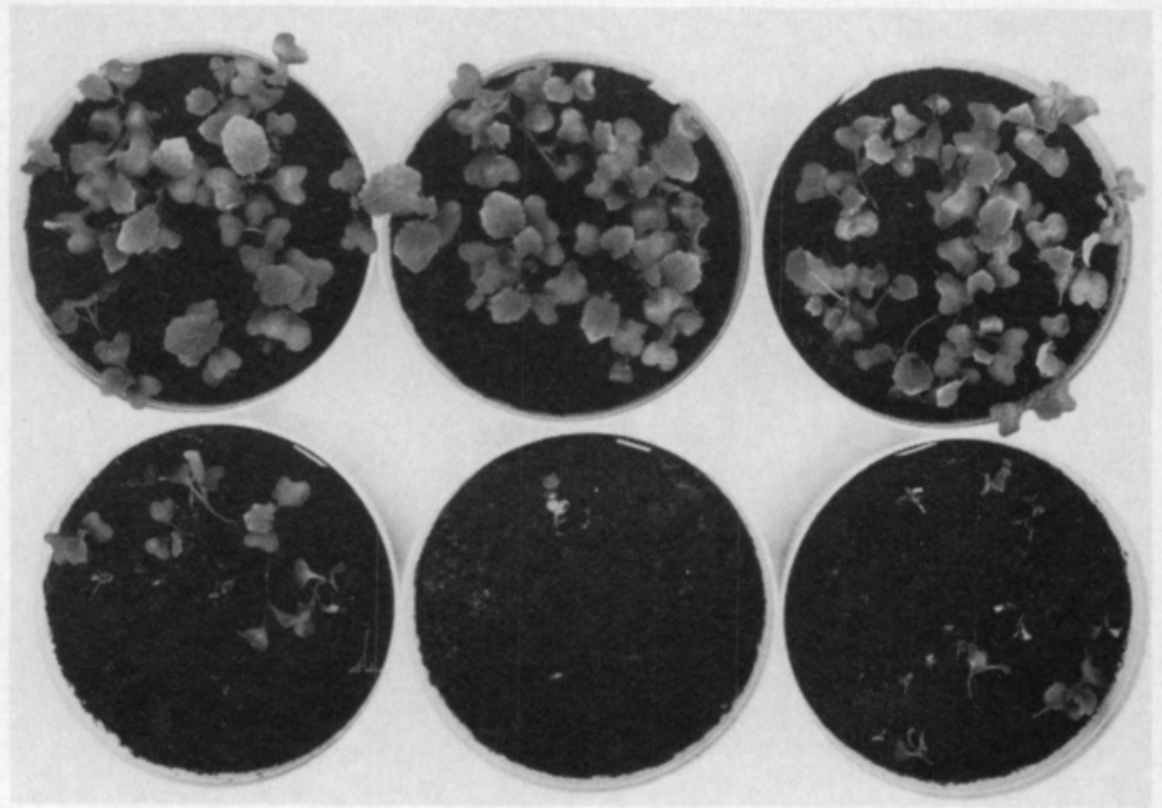

Fig. 4. Effect of Streptomyces seed treatment on soil-borne damping-off caused by Rhizoctonia solani on cauliflower. Upper row $=$ seeds treated with Streptomyces, bottom row $=$ untreated seeds.

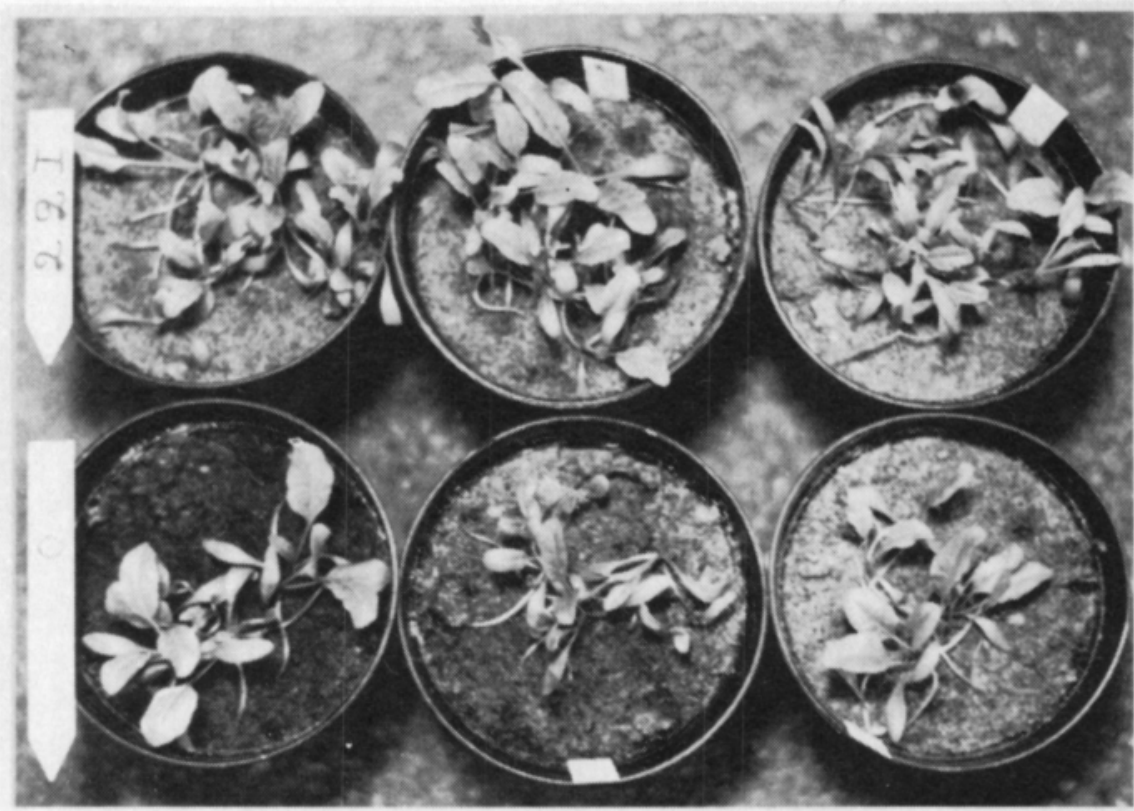

Fig. 5. Effect of treating the substrate with Streptomyces on damping-off caused by Pythium debaryanum on sugar beet. Upper row = sown layer treated with Streptomyces, bottom row $=$ no treatment. 
Treating the seeds with Streptomyces effectively controlled soil-borne damping-off caused by $R$. solani on cauliflower (Table 8). Combined seed and soil treatment with an aqueous solution of Streptomyces increased the incidence of damping-off in comparison to the seed treatment alone. Damping-off reached peak values when the soil was sprayed with a $10^{-2}$ dilution after sowing. The result was better when both greater and smaller concentrations were used. The same trend was evident with the nutrient suspension treatment, but the result was not statistically significant.

Spraying the seeding layer with Streptomyces significantly decreased the amount of soil-borne damping-off caused by Pythium debaryanum auct. non Hesse on sugar beet (Table 9).

Table 9. Effect of Streptomyces spp. isolates given as seed and soil treatment at different dilutions on soilborne damping-off caused by Pythium degaryanum on sugar beet. Peat infected with Pythium one week before sowing.

\begin{tabular}{|c|c|c|c|c|c|c|}
\hline & & \multicolumn{4}{|c|}{ Dilution made from stock Streptomyces suspension } & \multirow[b]{2}{*}{$\tilde{\mathrm{X}}$} \\
\hline & & $1 / 1$ & $1 / 5$ & $1 / 10$ & $1 / 20$ & \\
\hline & & \multicolumn{4}{|c|}{$\%$ of healthy seeds 6 weeks after sowing } & \\
\hline \multicolumn{7}{|c|}{ Soil treatment } \\
\hline Isolate 2 & & 36.2 & 40.0 & 39.0 & 42.8 & 39.5 \\
\hline \multirow[t]{2}{*}{ Isolate 6} & & 47.6 & 53.3 & 42.9 & 43.8 & 46.9 \\
\hline & $\overline{\mathrm{X}}$ & 41.9 & 46.7 & 41.0 & 43.3 & 43.2 \\
\hline \multicolumn{7}{|c|}{ Seed treatment } \\
\hline Isolate 2 & & 21.0 & 29.5 & 13.4 & 19.1 & 20.6 \\
\hline \multirow[t]{2}{*}{ Isolate 6} & & 30.5 & 19.1 & 16.2 & 7.6 & 18.4 \\
\hline & $\overline{\mathrm{X}}$ & 25.8 & 24.3 & 14.8 & 13.4 & 19.6 \\
\hline Control & $\overline{\mathrm{X}}$ & 24.8 & (emergence $61.1 \%$ ) & & & \\
\hline
\end{tabular}

F values: treatment $=64.6^{\circ *}$, isolates $=0.7$, dilutions $=1.7$, combined effect 2.8

\section{Discussion}

In the studies carried out by BROADBENT et al. (1971), 10-47 \% of the Streptomyces isolates were antagonistic to fungal pathogens, and in the studies carried out by COOPER and SHILTON (1949) $30 \%$. Between 75 and $80 \%$ of the isolates made from peat were antagonistic while all the isolates made from fine sand soil were ineffective. This would indicate that the Streptomyces species isolated from peat are strong antagonists in comparison to the Streptomyces strains isolated from other types of soil. This may explain, in part, the strong inhibitory effect shown by certain peat lots against plant pathogens since only some of the peat lots were found to have large Streptomyces populations (TAHVONEN 1982). Since the Streptomyces isolates 
tested here have not yet been identified in full, it is difficult to compare them with the results obtained by KNAUSS (1976). However, the antagonistic properties of the Streptomyces isolates obtained from peat are obviously at least as strong as the Streptomyces isolates obtained in many other studies (COOPER and SHILTON 1949, JOHNSON 1954, RANGASWAMI and ETHIRAJ 1962, BROADBENT et al. 1971, KNAUSS 1976, TURHAN 1981 a).

Peat appears to be a natural organic substrate for Streptomyces spp. where they are able to reproduce and spread, where the production of antibiotics is high and where the damage caused by fungal pathogens is restricted and inhibited effectively. The roots of growing plants apparently further stimulate the activity of Streptomyces spp. (COOPER and SHILTON 1949, RANGASWAMI and VEDYASEKAREN 1963), which certainly has a beneficial effect on the control of pathogens. Indications of plant roots having a stimulating effect have also been found with peat (TAHVONEN 1982).

The success of the biological control of Alternaria, Fusarium, Helminthosporium and Pythium fungi using Streptomyces isolates from peat appears to continue throughout the seedling stage at least, i.e. for 3-6 weeks. This is further evidence to show that this microbe thrives well in peat. The control result in new, non-disinfected peat is also good, the natural microflora still being present in the peat. In general, this sort of biological control result has been obtained from disinfected or partly disinfected substrates (JOHNSON 1954, LOCKWOOD 1958, BROADBENT et al. 1971, SCHER and BAKER 1980). However, TURHAN (1981 b) has obtained good results with Streptomyces treatment in the control of soil-borne pathogens in non-disinfected substrates. In the study carried out by BROADBENT et al. (1971), it was found that the pathogen-inhibiting effect of soil containing a number of different antagonistic species was not as high as soil where the number of antagonistic fungi was lower. Peat presumably contains only two significant antagonists, Trichoderma viride Pers. ex Fr. and Streptomyces spp. (TAHVONEN 1982). This may explain the good results obtained in biological control with Streptomyces spp. treatment in non-disinfected soil, too.

The experiments carried out here show rather reliably that the most common seed and soil-borne fungi causing damping-off can be controlled biologically in peat substrates by treating either the seeds or the soil with Streptomyces isolates obtained from peat. The control result in most of the experiments came close to the level of the healthy control plants. Even the soil-borne fungi, Rhizoctonia solani Kühn and Pythium debaryanum auct. non Hesse, could be controlled or restricted. This is usually extremely difficult or impossible to do by ordinary control measures.

Biological control methods for fungal pathogens in peat cultures require extensive studies in order to identify the best isolates and application techniques for the control of different pathogens, especially in long-term cultures. The number of factors involved in the preservation and growth of Streptomyces spp. isolates presupposes further extensive studies. A good example of the complexity of these phenomena is the experiment into the control of soil-borne $R$. solani, where seed treatment alone gave the bestresult and when seed treatment was combined with a soil surface treatment in 
which different dilution levels of the stock solution were used, the effectiveness of the biological control of damping-off was lost completely in the case of certain dilutions.

Acknowledgements: Pirkko Harju, M.Sc. and Kaija Karhunen, M.Sc. participated in carrying out the practical aspects of the experiments. Lahja Pesonen, Pentti Heinänen and Tauno Koivunen, staff members of the Department of Plant Pathology, have all helped in establishing and carrying out the experiments. Kemira Oy have assisted by paying the salaries of some of the assistants and providing materials. I would like to extend my sincere gratitude to all of the above mentioned persons.

\section{References}

BROADBENT, P., BAKER, K. F. \& WATERWORTH, Y. 1971. Bacteria and Actinomycetes antagonistc to fungal root pathogens in Australian soils. Aust. J. Biol. Sci. 24: 925-944.

COOPER, W. E. \& SHILTON, S. J. P. 1949. Antibiosis of Actinomyces strains to Pythium arrbenomanes, and Rhizoctonia solani. Phytopath. 39: 5.

JOHNSON, L. F. 1954. Antibiosis in relation to Pythium root rot of sugarcane and corn. Phytopath. 44: 69-73.

KNAUSS, J. F. 1976. In vitro antagonistic activity of several Streptomyces spp. against species of Pythium and Phytophthora. Pl. Dis. Rep. 60: 846-850.

LOCKWOOD, J. L. 1958. Streptomyces spp. as a cause of natural fungitoxity. Phytopath. $48: 395$.

RANGASWAMI, G. \& ETHIRAJ, S. 1962. Antibiotic production by Streptomyces sp. in unamended soil. Phytopath. 52: 989-992.

- \& VEDYASEKAREN, P. 1963. Antibiotic production by Streptomyces spp. in corn rhizosphere. Phytopath 53: 995-997.

SCHER, F. M. \& BAKER, R. 1980. Mechanism of biological control in a Fusarium-suppressive soil. Phytopath. 70: 412-417.

TAHVONEN, R. 1982. The suppressiveness of Finnish light coloured Sphagnum peat. J. Scient. Agric. Soc. Finl. 54: 357-369.

TURHAN, G, 1981 a. A new race of Sreptomyces ochraceisclerticus in the biological control of some soilborne plant pathogens I. Effects of the isolate $\mathrm{C} / 2-9$ on some of the most important soil-borne fungi in vitro. Z. Pfl. krankheiten und Pfl. schutz 88: 373-381.

- 1981 b. A new race of Streptomyces ochraceiscleroticus in the biological control of some soil-borne plant pathogens II. In vivo studies on the possibilities of using $\mathrm{C} / 2-9$ agains some important diseases. Z. Pfl.krankheiten und Pfl. schutz 88: 422-434.

Ms received October 29, 1982. 


\title{
Esitutkimuksia turpeesta eristettyjen Streptomyces spp. -isolaattien käytöstä maa- ja siemenlevintäisten tautien biologisessa torjun- nassa turveviljelyssä
}

\author{
Risto Tahvonen \\ Helsingin yliopiston kasvipatologian laitos, 00710 Helsinki 71
}

Vuosina 1975-79 tehdyissä selvityksissä vaalean rahkaturpeen sienitautien estovaikutuksista oli todettu, että turpeesta eristetyt Streptomyces spp. -isolaatit, joita seuraavassa kutsutaan sädesieniksi, estivät tehokkaasti sienten kasvun ravintoalustalla ja pystyivät vähentämään merkittävästi taimipoltetta kukkakaalilla. Vuosina 1979-81 tehtiin Helsingin yliopiston kasvipatologian laitoksella alustavia tutkumuksia sädesienien käyttömahdollisuuksista biologisessa kasvitautien torjunnassa turvealustalla.

Sädesieni-isolaatteja testattiin ravintoalustatestein Alternaria brassicicola Wiltshire, Fusarium culmorum (W. G. Smith) Sacc., Pythium debaryanum auct. non Hesse ja Rhizoctonia solani Kühn -sieniä vastaan. Kasvatuskokeissa olivat testikasveina kukkakaali, ohra ja sokerijuurikas. Kukkakaalin siemenet saastutettiin $A$. brassicicola ja $R$. solani -sienellä tai kasvualustana käytetty turve saastutettiin viikko ennen kylvöä $R$. solani - sienellä. Ohralla käytettiin $F$. culmorum ja Helminthosporium sativum Pammel, King \& Bakke -sienellä keinosaastutettua siementä ja sokerijuurikkaalla kasvualusta oli saastutettu viikko ennen kylvöä $P$. debaryanum -sienellä. Siemeniä ja maata käsiteltiin sädesienestä tehdyillä vesi- ja ravinnesuspensioilla sekä näiden vesilaimennoksilla. Sädesienien taudintorjuntakykyä mitattiin taimettumisella ja taimipoltteen määrällä (kukkakaali ja sokerijuurikas) sekä orastumisella, tyvitaudin runsaudella ja tuorepainolla (ohra).

Useimmat turpeesta eristetyistä 35 sädesieni-isolaatista estivät ravintoalustalla testisienien kasvua, mutta hietamaasta eritetyt 20 sädesieni-isolaattia, jotka oli saatu Mikrobiologian laitokselta Viikistä, eivät olleet lainkaan tehokkaita testattua $F$. culmorum -sientä vastaan.

Kukkakaalin siementen peittaaminen sädesienisuspensiolla esti tai vähensi merkitsevästi $A$. brassicicola ja $R$. solani -sienen aiheuttamaa taimipoltetta. Maan käsittely sädesienisuspensiolla oli tehokkaampi kuin siemenkäsittely ohran $F$. culmorum -tyvitaudin torjunnassa. Saastuttamattomien ohran siementen sädesienikäsittely lisäsi oraiden tuorepainoa verrattuna käsittelemättömïn. Kylvökerroksen sädesienikäsittely vähensi merkitsevästi $P$. debaryanum -sienen aiheuttamaa taimipoltetta sokerijuurikkaalla.

Nyt saadut tulokset antavat viitteitä siitä, että turveviljelyssä on mahdollista hallituissa kasvihuoneolosuhteissa torjua tai ainakin rajoittaa sienitautien tuhoja biologisesti. Biologisen torjunnan käyttömuotoina olisivat siementen peittauskäsittelyt ja mahdollisesti kylvökerroksen käsittelyt desinfioidun tai uuden turpeen sienitautien estovaikutuksen palauttamiseksi tai kohottamiseksi. Käytännön sovellutukset vaativat kuitankin vielä laajoja jatkotutkimuksia tärkeimmillä kasvihuoneissa viljeltävillä kasveilla. 